\title{
Retraction Note: Impact of weight loss diet associated with flaxseed on inflammatory markers in men with cardiovascular risk factors: a clinical study
}

Roberta Soares Lara Cassani ${ }^{1}$, Priscila Giacomo Fassini ${ }^{2 *}$, Jose Henrique Silvah ${ }^{2}$, Cristiane Maria Mártires Lima ${ }^{2}$ and Júlio Sérgio Marchini ${ }^{2}$

The Editor is retracting this article [1] because of concerns raised after publication with respect to the methods and the statistical analysis [2] which the authors have not been able to adequately address [2]. We apologise to all affected parties for the inconvenience caused. All authors support this retraction.

\section{Author details}

${ }^{1}$ Institute of Nutrition, Itu, São Paulo, Brazil. ${ }^{2}$ Department of Medicine,

Division of Medical Nutrition, Ribeirão Preto Medical School, University of São

Paulo, Avenida Bandeirantes, 3900 Bairro Monte Alegre, Ribeirão Preto, São

Paulo CEP: 14049-900, Brazil.

Received: 21 April 2016 Accepted: 21 April 2016

Published online: 07 June 2016

\section{References}

1. Cassani RSL, Fassini PG, Silvah JH, Lima CMM, Marchini JS. Impact of weight loss diet associated with flaxseed on inflammatory markers in men with cardiovascular risk factors: a clinical study. Nutr J. 2015;14:5.

2. Dimova RB, Allison, DB. Inappropriate statistical method in a parallel-group randomized controlled trial results in unsubstantiated conclusions. Nutr J 2016, doi:10.1186/s12937-016-0163-z.

\footnotetext{
* Correspondence: priscilafassini@usp.br

${ }^{2}$ Department of Medicine, Division of Medical Nutrition, Ribeirão Preto Medical School, University of São Paulo, Avenida Bandeirantes, 3900 Bairro

Monte Alegre, Ribeirão Preto, São Paulo CEP: 14049-900, Brazil

Full list of author information is available at the end of the article
} 